\title{
Nonword Repetition in Terms of Subtypes of Children with Speech Sound Disorders
}

\author{
Seunghee Ha \\ Division of Speech Pathology and Audiology, Audiology and Speech Pathology Research Institute, Hallym University, Chuncheon, Korea
}

Correspondence: Seunghee $\mathrm{Ha}, \mathrm{PhD}$ Division of Speech Pathology and Audiology, Audiology and Speech Pathology Research Institute, Hallym University, 1 Hallymdaehak-gil, Chuncheon 24252, Korea

Tel: +82-33-248-2215

Fax: $+82-33-256-3420$

E-mail: shha@hallym.ac.kr

Received: October 5, 2020

Revised: November 6, 2020

Accepted: November 6, 2020

\begin{abstract}
Objectives: This study aimed to examine nonword repetition performances between children with speech sound disorders (SSD) with and without co-occurring language disorders and in subgroups of SSD by linguistic symptomatology. Methods: This study included 206 typically developing children, 120 children with SSD and 44 children with language impairments aged 3 to 7 years. All participants were asked to repeat nonword lists and the percent of correct nonword repetitions were measured by items, syllables, and phonemes. Nonword repetition performances were compared among typically developing children, children with SSD only, co-occurring SSD with language impairment, and language impairment only by controlling age and percentage of consonants correct (PCC) as covariates. Four subgroups of SSD by linguistic symptomatology, articulation disorder, phonology delay, consistent phonological disorder, and inconsistent phonological disorder were examined for whether they show different performances in nonword repetition tasks. Results: Children with SSD only showed significantly higher performance compared with the other three groups including typically developing children after controlling for age and PCC. Children with co-occurring SSD with language impairment showed the lowest performance. Inconsistent phonological disorders showed a significantly lower percent correct nonword repetitions measured by phonemes than the other three subgroups of SSD classified by linguistic symptomatology. Conclusion: This study suggested that nonword repetition tasks could help us identify children with SSD with co-occurring language impairment or inconsistent phonological disorders who might have different underlying deficits on speech-language process from other subtypes of SSD.
\end{abstract}

Keywords: Speech sound disorders, Co-occurring language impairment, Subtypes, Nonword repetition
말소리장애 아동이 말소리 산출상의 어려움 외에 동시에 보이는 문제를 확인하는 것은 장애의 원인과 본질을 이해하고 적절한 중 재 계획을 세우는데 필수적이다. 말소리장애 아동은 의사소통장 애 가운데 언어장애를 동시에 보이는 비율이 가장 높은 것으로 보 고되고 있다(Bernthal, Bankson, \& Flipsen, 2017; Kim, Kim, Ha, \& Ha, 2015; Ko, Seo, Oh, \& Kim, 2017; Shriberg \& Austin, 1998). Shriberg와 Austin (1998)은 말소리장애와 언어장애를 동시에 보이는 아동의 비율에 대해서 광범위한 문헌조사와 연구를 실시하였다. 연구자들은 연구마다 대상자 선정 기준과 연구방법이 다르기 때문 에 말소리장애와 언어장애의 동반 비율이 다양하게 나타나지만,
학령전기 말소리장애 아동의 약 $60 \%$ 가 언어장애를 보인다고 결론 지었다. 국내 연구로 Kim 등(2015)은 말소리장애를 주로 평가하거 나치료하는 임상가를 대상으로 설문조사를 실시하였는데, 말소리 장애 아동 중 수용 및 표현언어 문제가 확인된 경우는 약 18-26\%이 고 의심되는 아동까지 포함하면 약 $55 \%$ 에 달하였다. 또한 4-6세 말 소리장애 아동을 대상으로 언어장애 동반 여부를 살펴본 Ko 등 (2017)은 말소리장애 아동의 언어장애 동반율을 $57.8 \%$ 로 보고하 였다. 이와 비슷하게 $\mathrm{Pi}$ 와 $\mathrm{Ha}$ (2020)에서도 133명의 말소리장애 아 동 중 수용어휘 발달지연을 보인 아동은 약 $49 \%$ 이고, 표현어휘 발 달이 지연된 아동은 약 $57 \%$ 로 나타났다. 국내외 연구를 종합하면 
말소리장애 아동의 절반 이상이 언어문제를 동시에 보일 가능성이 있다. 말소리장애와 언어장애를 동시에 보이는 아동은 말소리장애 만 보이는 아동과는 근본적으로 다른 원인으로 인해 말소리 산출 상의 어려움을 보일 수 있다. 예를 들어 Macrae와 Tyler (2014)는 말 소리장애만을 보이는 아동과 언어장애를 동시에 보이는 말소리장 애 아동을 비교하였는데 두 말소리장애 집단이 전반적인 말소리 정 확도 상에는 차이가 없었으나 오류 유형별 발생 비율은 서로 달랐 다. 말소리장애만을 보이는 아동과 비교해 언어장애를 동시에 보이 는 말소리장애 아동은 생략 오류가 유의하게 많았지만 왜곡 오류 는 적었다. 연구자는 언어장애를 동반한 말소리장애 아동이 생략 오류를 많이 보이는 것은 목표 음소에 대한 기저 표상이 존재하지 않음을 의미하고, 언어 체계상에 광범위한 결함을 반영한다고 해 석하였다.

말소리장애와 동반 문제를 확인하는 것과 비슷하게 말소리장애 의 하위유형을 분류하여 특성을 살펴보는 것도 말소리장애 아동 이 보이는 어려움의 본질을 이해하는데 도움이 된다. 말소리장애 하위유형에 관한 여러 제안 중 Stackhouse와 Wells (1997)는 심리 언어학적 모델에 근거하여 말소리장애 아동을 말 처리 과정 중 결 함을 보이는 영역에 따라 분류할 수 있다고 제안하였다. Dodd (1995, 2005)는 심리언어학적 모델에 근거한 분류법이 타당하다고 동의하 였지만 실제 아동이 말 처리 과정 중 어느 영역에서 결함을 보이는 지 확인하는 것이 쉽지 않은 작업임을 지적하면서 분류가 보다 용 이한 접근법을 제안하였다. $\operatorname{Dodd}(1995,2005)$ 는 언어학적 증상 즉 표면 오류 유형에 따라 말소리장애를 조음장애, 음운지연, 일관적 음운장애, 비일관적 음운장애로 분류하였다. 언어학적 증상으로 분류하였지만 네 집단은 말 처리 과정에서 서로 다른 단계에서의 어려움으로 인해 말소리 산출상의 문제를 보이는 것으로 해석이 가능하다. 예를 들어 조음장애는 말 처리 과정에서 마지막 단계인 말 운동 실행 단계에서의 결함으로만 발생하는 반면에 비일관적 음운장애는 음운표상을 비롯한 말 처리의 광범위한 부분에서의 결함과 관계가 있을 수 있다(Holm, Crosbie, \& Dodd, 2007).

말소리장애와 동반 장애와의 관계를 확인하거나 말소리장애 하 위유형을 감별진단하는 것은 아동의 말소리장애의 기저 결함의 본 질을 확인하고 이해하는 과정이다. 궁극적으로 말소리장애의 기저 결함을 확인하고 그 부분을 직접적으로 지원하거나 향상시킬 수 있는 중재를 제공하는 것이 중요하다. 말소리장애의 기저 결함을 파악하고 감별진단하는데 유용하게 사용될 수 있는 검사로 무의 미 낱말 따라말하기 과제가 있다. 무의미 낱말을 듣고 정확하게 따 라말하기 위해서는 음향학적 정보에 대한 청지각 및 처리능력이 필 요하고, 음운기억과 음운표상의 견고함에 의존하면서 음운 부호화 (phonological encoding) 과정을 거치게 된다. 이 후 무의미 낱말에 포함된 연속적인 음운정보를 위한 조음 움직임을 계획하고 프로그 래밍하여 정확하게 산출할 수 있게 된다. 따라서 무의미 낱말 따라 말하기는 아동의 말-언어 처리과정에서 입력(input)-표상(representation)-산출(output)에 걸쳐 여러 영역의 발달 상황과 견고함을 반영하는 과제이다. 일반 아동은 성장하면서 말-언어 발달이 진행 됨에 따라 말-언어 처리 과정의 각 영역들이 서로 상호작용하고 영 향을 끼치면서 발달하여 무의미 낱말 따라말하기의 수행력도 점진 적으로 증가하게 된다(Gathercole \& Adams, 1993; Stackhouse \& Wells, 1997).

일련의 말-언어 처리 과정에서 한 영역 또는 여러 영역에서의 발 달이 지연 또는 제한을 보일 경우 언어, 읽기, 또는 말 문제로 나타나 고 더불어 무의미 낱말 따라말하기 상의 어려움을 보이게 된다. 따 라서 무의미 낱말 따라말하기 능력은 언어, 읽기, 말소리장애 영역 에서 활발하게 연구되었으며, 장애를 확인하는 진단표지로서 제안 되어 왔다(Conti-Ramsden, Botting, \& Faragher, 2001; Conti-Ramsden \& Hesketh, 2003; Ellis Weismer et al., 2000; Estes, Evans, ElseQuest, 2007; Shriberg et al., 2009; Snowling \& Stackhouse, 1983). 말소리장애 아동의 경우 말 지각, 음운표상, 말 운동 계획 및 프로 그래밍, 실행 단계에서 하나 또는 여러 단계에서의 문제로 인해 말 소리 오류를 보이게 된다. 따라서 아동의 무의미 낱말 따라말하기 의 수행력을 통해 아동의 말소리 장애의 기저 결함을 이해하는데 도움이 된다. 예를 들어 Snowling과 Stackhouse (1983)는 무의미 낱말 따라말하기 과제가 말 운동 프로그램 및 계획 상의 결함을 확 인할 수 있기 때문에 아동기 말 실행증을 포함하여 말소리장애 아 동의 감별진단에도 유용하다고 제안하였다. 또한 Shriberg 등(2005) 은 유전적 소인에 의해 말소리장애를 보이는 아동은 다른 말소리장 애 아동에 비해 유의하게 낮은 무의미 낱말 따라말하기를 보였다 고 보고하였다. 이 연구를 바탕으로 Shriberg 학자와 그의 동료는 유전적 소인에 의한 말소리장애 아동 연구를 확장하기 위해 진단 도구로서 말소리장애 아동을 위한 무의미 낱말 따라말하기 검사도 구를 개발하기도 하였다(Shriberg et al., 2009). 연구자들은 주로 단 순언어장애 진단에 사용되던 기존의 무의미 낱말 따라말하기 과제 를 말소리장애 아동에게 실시할 경우 습관적인 조음 오류로 인해 무의미 낱말 따라말하기 점수가 낮아질 수 있음을 지적하였다. 따 라서 오조음의 영향을 최소한으로 받으면서 타당하게 따라말하기 능력을 평가하기 위해 비음, 파열음, 저모음 [a]로만 구성된 검사어 목록을 제안하였다. 이와 비슷하게 국내에서도 $\mathrm{Ha}, \mathrm{Kim}, \mathrm{Seo}$ 와 Pi (in press)가 말소리장애 아동이 일반적으로 오류를 보이는 파찰음, 마찰음, 탄설음 등을 제외하고 일찍 습득되는 비음, 파열음, 설측음 
으로 구성한 무의미 낱말 따라말하기 과제를 개발하였다. 연구자 들은 자음의 난이도 뿐 만 아니라 모음으로만 구성된 무의미 낱말 도 포함하면서 조음정확도 보다는 음운처리와 말 운동 프로그램 을 반영하는 과제가 될 수 있도록 하였다.

본 연구에서는 말소리장애 평가를 위해 고안된 무의미 낱말 과 제(Ha et al., in press)를 이용해서 말소리장애 동반문제와 하위유 형에 따라 무의미 낱말 따라말하기 수행력을 비교하면서 무의미 낱말 따라말하기 검사의 타당성과 유용성을 점검해보고자 한다. 구체적으로 개발된 무의미 낱말 따라말하기 과제가 언어장애 동반 여부와 언어학적 증상에 따라 분류한 말소리장애 하위유형의 특성 을 구별하여 제시할 수 있는지 살펴보고자 한다.

\section{연구방법}

\section{대상자}

본 연구는 3세부터 7세 11 개월에 해당하는 일반 아동 206명(남: 101 명, 여: 105 명)과 말소리장애 및/또는 언어장애 아동 164 명(남: 104 명, 여: 60명)의 자료를 토대로 이루어졌다. 말소리장애 아동을 언어장애 동반 여부에 따라서 분류하면 언어장애를 동반하지 않은 순수말소리장애 아동 78 명(남: 49 명, 여: 29명), 언어장애를 동반한 말소리장애 아동 42 명(남: 30 명, 여: 12 명)이었다. 그리고 언어장애 만 있는 아동은 44 명(남: 25 명, 여: 19 명)이었다. 또한 120 명의 말소 리장애 아동을 Dodd $(1995,2005)$ 가 제안한 언어학적 증상에 기반 하여 $\mathrm{Pi}$ 와 $\mathrm{Ha}$ (2020)에서 사용한 기준에 따라 조음장애 34 명, 음운 지연 59명, 일관적 음운장애 17 명, 비일관적 음운장애 10 명으로 분 류하였다.

주양육자나 유치원 및 어린이집 교사의 보고에 따라 청력을 포 함한 감각과 정서 상에 문제가 없고 신체적, 인지적, 신경학적 발달 과 관련된 의학적인 진단을 받지 않은 아동 만을 본 연구에 포함하 였다. 일반 아동은 아동용 발음평가(APAC; Kim, Pae, \& Park, 2007) 에서 백분위수 16 이상이며, 수용·표현어휘력 검사(REVT, Kim, Hong, Kim, Chang, \& Lee, 2009) 중 수용어휘력 검사와 표현어휘 력 검사에서 -2 표준편차 이상인 아동이었다. 순수말소리장애 아 동은 APAC 결과 백분위수 16 미만이며 REVT 결과수용어휘력 검 사와 표현어휘력 검사 모두에서 -2 표준편차 이상인 아동이었다. 언 어장애를 동반한 말소리장애 아동은 APAC 결과 백분위수 16 미 만이며 REVT 결과 수용어휘력과 표현어휘력 검사 중 하나 또는 두 검사 모두에서 -2 표준편차 미만인 아동이었다. 언어장애 아동 은 APAC 결과 $16 \%$ ile 이상이고 REVT 결과 수용어휘력 검사와 표 현어휘력 검사에서 -2 표준편차 미만인 아동이었다. 최종적으로 본
Table 1. Number of participants, age, and percent consonants correct (PCC) of each groups

\begin{tabular}{lcccc}
\hline Groups & TD & SSD & SSD+LD & LD \\
\hline $\mathrm{N}$ & 206 & 78 & 42 & 44 \\
Age (months) & $67.24(19.03)$ & $64.37(16.41)$ & $69.17(15.92)$ & $67.95(20.62)$ \\
PCC (\%) & $94.81(6.23)$ & $80.82(12.64)$ & $82.82(9.03)$ & $94.09(7.58)$ \\
\hline Subgroups of SSD & $\mathrm{AD}$ & $\mathrm{PD}$ & $\mathrm{CPD}$ & ICPD \\
\hline $\mathrm{N}$ & 34 & 59 & 17 & 10 \\
Age (months) & $78.06(11.14)$ & $61.34(16.02)$ & $67.24(12.31)$ & $51.00(14.33)$ \\
PCC (\%) & $90.76(5.46)$ & $79.83(8.90)$ & $77.23(13.00)$ & $67.43(15.28)$ \\
\hline
\end{tabular}

Values are presented as mean (SD).

$\mathrm{TD}=$ typically developing children; SSD = speech sound disorders; $S S D+L D=$ speech sound disorders with co-occurring language disorders; $L D=$ language disorders; $\mathrm{AD}=$ articulation disorder; $\mathrm{PD}=$ phonological delay; $\mathrm{CPD}=$ consistent phonological disorder; $I C P D=$ inconsistent phonological disorder.

연구에서 구성된 집단의 대상자 수와 연령, $\mathrm{APAC}$ 의 자음정확도는 Table 1과 같다.

\section{자료수집}

자료수집은 어린이집, 유치원, 또는 아동의 가정에서 언어병리학 전공 대학원생 6 명에 의해서 이루어졌다. 자료수집에 앞서서 참여 대학원생은 무의미 낱말 따라말하기 과제 시행 방법을 포함해서 모든 자료수집 방법과 절차에 대해서 훈련을 받았다. 자료수집은 연구 대상자 포함 기준을 확인하기 위해서 모든 아동에게 APAC, REVT, 한국 조음음운 프로파일(K-APP, Ha et al., 2020) 검사도구 를 무작위 순서로 제시하여 평가하였다. APAC 검사 결과를 바탕 으로 말소리장애로 진단된 아동은 K-APP의 일관성 검사와 오류패 턴 분석 결과를 바탕으로 $\mathrm{Pi}$ 와 $\mathrm{Ha}$ (2020) 연구에 제시된 바대로 조 음장애, 음운지연, 일관적 음운장애, 비일관적 음운장애로 하위유 형을 나누었다.

본 연구에서는 K-APP의 하위검사로 포함된 무의미 낱말을 이용 하였으며, Jung과 $\mathrm{Ha}$ (2017)에 사용된 무의미 낱말 리스트와 동일 하다. 무의미 낱말 검사는 총 25 개의 검사어로 2 음절에서부터 5 음 절까지 음절길이와 구조의 복잡성이 점진적으로 증가하고, 조음난 이도가 상대적으로 낮은 파열음, 비음, 설측음으로만 구성되어 있 다. 본 연구에서 사용한 무의미 낱말은 아동이 오조음하는 음소의 영향을 최소한으로 받으면서 청각적 변별 및 지각 능력, 음운 표상 및 음운기억, 말 운동 프로그램이 반영될 수 있도록 조음난이도가 상대적으로 낮은 음소로만 구성되었다. 무의미 낱말 따라말하기 검사를 실시할 때는 조용한 환경에서 마주 본 상태에서 아동에게 낱말을 하나씩 들려주고 그대로 따라말하도록 하였다. 아동이 주 의집중을 하지 않거나 무반응일 경우에는 두 번까지 목표 무의미 
낱말을 더 들려주면서 기회를 주었다. 모든 자료수집 과정은 오디 오녹음으로 기록하였다.

\section{자료분석}

자료분석은 자료수집에 참여한 대학원생 중 일반과 말소리장애 아동의 음성 자료를 이용하여 듣기와 전사 훈련을 집중적으로 받 은 언어병리학 전공 대학원생 4 명에 의해서 이루어졌다. 아동의 반 응을 모두 음성 전사 한 후 무의미 낱말(문항), 음절, 음소 단위로 정확도를 구하였다. 총 25 개의 문항과 76 개의 음절, 153 개의 음소를 토대로 정확하게 따라말한 문항, 음절, 음소에 각각 1 점씩 부과하고 틀린 경우에는 0 점을 부과하여 정확한 문항, 음절, 음소의 비율을 구하였다.

\section{신뢰도}

무의미 낱말에 대한 음성 전사의 신뢰도는 전체 대상 아동 중 무 작위로 선정한 총 30 명의 자료를 바탕으로 살펴보았다. 자료분석에 참여한 4 명의 대학원생이 30 명의 자료를 각각 독립적으로 전사를 한 뒤 전사자 2 명씩 가능한 모든 쌍을 이루어 전사의 일치 여부를 살펴보았다. 즉 (두 명의 전사자가 서로 일치한 음소 수)/(검사어 내 전체 음소 수)* 100 으로 전사자 간 신뢰도를 구하였다. 전사가 간 신 뢰도는 86-94\%로 나타났다.

\section{통계 분석}

언어장애 동반 여부에 따른 말소리장애 아동의 무의미 낱말 따 라말하기 특성을 파악하고자 일반 아동과 언어장애 동반 여부에 따른 말소리장애 2집단, 언어장애, 총 4집단을 독립변수로 설정하 고 문항, 음절, 음소 별 정확도를 종속변수로 설정하였다. 무의미 낱 말 따라말하기는 연령과 자음정확도와 유의한 상관관계가 있다. 따라서 연령과 APAC 검사의 자음정확도를 공변량으로 통제하는 공분산분석(ANCOVA)을 실시하고 사후검정으로 Bonferroni 검 정을 실시하였다. 마찬가지로 언어학적 증상에 따른 말소리장애 하 위집단 별 수행력 비교를 위해서도 연령과 자음정확도를 공변량으
로 하는 공분산분석을 실시하고 사후검정을 실시하였다. 집단 별 수행력으로 공분산분석을 통해 연령과 자음정확도를 통제한 후의 추정 주변 평균(estimated marginal means)과 표준오차를 보고하 였다. 모든 유의 수준은 $p<.05$ 로 설정하였다.

\section{연구결과}

\section{언어장애 동반 여부에 따른 말소리장애 아동의 수행력 비교}

일반 아동과 언어장애를 동반하지 않은 순수말소리장애, 언어장 애를 동반한 말소리장애, 언어장애만을 보이는 아동의 무의미 낱 말 따라말하기 수행력을 분석 단위에 따라 살펴본 결과는 Table 2 와 같다. 연령과 자음정확도를 공변량으로 통제한 후에 문항, 음절, 음소 단위별 정확도의 집단 간 추정 주변 평균을 살펴보면, 순수말 소리장애 아동이 일반 아동보다 높게 나타나 네 집단 중에 가장 높 은 수행력을 보였으며, 언어장애를 동반한 말소리장애 아동이 가장 낮았다. 연령과 자음정확도를 공변량으로 하는 공분산분석 결과, 무의미 낱말 따라말하기의 문항 $\left(F_{(3,364)}=15.247, p<.001, \eta_{\mathrm{p}}{ }^{2}=.112\right)$, 음절 $\left(F_{(3,364)}=12.824, p<.001, \eta_{p}{ }^{2}=.096\right)$, 음소 $\left(F_{(3.364)}=10.217, p<\right.$ $\left..001, \eta_{\mathrm{p}}{ }^{2}=.078\right)$ 정확도 모두 집단 간 유의한 차이가 나타났다. 사후 분석 결과, 먼저 문항 정확도는 일반 아동과 순수말소리장애 집단 은 각각 대응 비교한 다른 세 집단과 모두 유의한 차이를 보였으며 $(p<.05)$, 말소리장애를 동반한 언어장애와 언어장애 집단은 서로 유의한차이를 보이지 않았다. 음절과 음소 정확도에서는 순수말소 리장애 집단과 다른 세 집단 간 유의한 차이를 보였으나 $(p<.05)$, 일 반 아동과 언어장애를 동반한 말소리장애와 언어장애 집단 간에 는 서로 유의한차이를 보이지 않았다.

\section{말소리장애 하위유형 별 수행력 비교}

말소리장애 아동을 조음장애, 음운지연, 일관적 음운장애, 비일 관적 음운장애로 분류한 뒤에 무의미 낱말 따라말하기 수행력을 분석 단위에 따라 살펴본 결과는 Table 3 과 Figure 1 과 같다. 언어장 애 동반 여부에 따른 말소리장애 아동의 수행력과 마찬가지로 연령

Table 2. Estimated marginal means and standard errors of percent correct nonword repetitions by units in typically developing children, children with SSD with and without $L D$, children with $L D$

\begin{tabular}{|c|c|c|c|c|c|c|}
\hline Measures by units (\%) & TD & SSD & $S S D+L D$ & LD & $F$ & Post-hoc \\
\hline Item & $68.49(1.10)$ & $75.51(1.89)$ & $59.06(2.39)$ & $61.48(2.19)$ & $15.247^{*}$ & $\mathrm{SSD}+\mathrm{LD}=\mathrm{LD}<\mathrm{TD}<\mathrm{SSD}$ \\
\hline Syllable & $85.84(.62)$ & $90.44(1.06)$ & $82.23(1.34)$ & $82.50(1.23)$ & $12.824^{*}$ & $\mathrm{SSD}+\mathrm{LD}=\mathrm{LD}=\mathrm{TD}<\mathrm{SSD}$ \\
\hline Phoneme & $92.19(5.50)$ & $94.82(.72)$ & $89.68(.90)$ & $90.35(.83)$ & $10.217^{*}$ & $S S D+L D=L D=T D<S S D$ \\
\hline
\end{tabular}

Values are presented as estimated marginal mean (standard error).

$\mathrm{TD}=$ typically developing children; $\mathrm{SSD}=$ speech sound disorders; $\mathrm{SSD}+\mathrm{LD}=$ speech sound disorders with co-occurring language disorders; $\mathrm{LD}=$ language disorders . ${ }^{*} p<.001$. 
Table 3. Estimated marginal means and standard errors of percent correct nonword repetitions of percent correct nonword repetitions by units in 4 subgroups of children with SSD

\begin{tabular}{lcccccc}
\hline Measures by units (\%) & AD & PD & CPD & ICPD & $F$ & Post-hoc \\
\hline Item & $68.56(3.43)$ & $59.33(2.33)$ & $60.51(4.33)$ & $51.15(6.03)$ & 2.156 & \\
Syllable & $85.37(1.91)$ & $81.75(1.29)$ & $80.67(2.41)$ & $70.95(3.35)$ & $4.056^{*}$ & CPD=PD=AD, ICPD=CPD, ICPD $<$ PD $<$ AD \\
Phoneme & $92.04(1.31)$ & $89.65(.89)$ & $89.33(1.65)$ & $81.30(2.30)$ & $4.847^{*}$ & ICPD $<$ CPD=PD=AD \\
\hline
\end{tabular}

Values are presented as estimated marginal mean (standard error).

$\mathrm{AD}=$ articulation disorder; $\mathrm{PD}=$ phonological delay; $\mathrm{CPD}=$ consistent phonological disorder; $\mathrm{ICPD}=$ inconsistent phonological disorder. ${ }^{*} p<.01$.

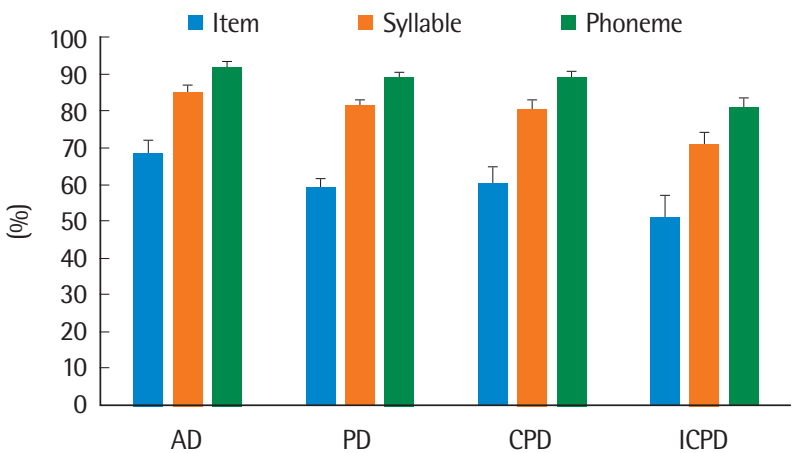

Figure 1. Percent correct nonword repetitions in subgroups of children with speech sound disorders (SSD).

$\mathrm{AD}=$ articulation disorder; $\mathrm{PD}=$ phonological delay; $\mathrm{CPD}=$ consistent phonological disorder; ICPD = inconsistent phonological disorder.

과 자음정확도를 공변량으로 통제한 후에 문항, 음절, 음소 단위 별 정확도의 집단 간 추정 주변 평균과 표준오차를 살펴보았다. 조음 장애가 문항, 음절, 음소 단위별 정확도 모두에서 다른 세 말소리장 애 집단과 비교해 가장 높았으며, 비일관적 음운장애가 가장 낮은 수행력을 보이면서 무의미 낱말 따라말하기 과제의 어려움이 두드 러지게 나타났다. 음운지연과 일관적 음운장애는 비슷한 수치의 정확도를 보였다. 공분산분석 결과, 무의미 낱말 따라말하기의 문 항 정확도는 말소리장애 하위 집단 간 유의한 차이를 보이지 않았 으나 $\left(F_{(3,114)}=2.156, p=.097, \eta_{\mathrm{p}}{ }^{2}=.54\right)$, 음절 $\left(F_{(3,114)}=4.056, p=.009\right.$, $\left.\eta_{\mathrm{p}}{ }^{2}=.096\right)$ 과 음소 $\left(F_{(3,14)}=4.847, p=.003, \eta_{\mathrm{p}}^{2}=.113\right)$ 정확도에서는 집단 간 유의한 차이가 나타났다. 사후검정 결과, 음절 수준에서는 비일관적 음운장애는 조음장애와 음운지연보다 유의하게 낮은 정 확도를 보였다 $(p<.05)$. 음소 수준에서는 비일관적 음운장애 집단 이 다른 세 말소리장애 집단과 비교해 유의하게 낮은 정확도를 보 였다 $(p<.05)$.

\section{논의 및 결론}

본 연구는 말소리장애 평가를 위해 고안된 무의미 낱말 따라말
하기 과제를 이용하여 언어장애 동반 여부와 언어학적 증상에 따 라 말소리장애 아동이 무의미 낱말 따라말하기의 수행력이 어떠한 지 살펴보고자 하였다. 무의미 낱말 따라말하기 수행력은 말 처리 과정의 다양한 영역과 밀접한 관련이 있지만 자음정확도로 평가한 조음 능력과도 높은 상관관계를 보인다. 또한 아동이 성장함에 따 라 말 처리 과정의 전반에 걸쳐 발달이 이루어지면서 점진적으로 무의미 낱말 따라말하기의 수행력이 증가하므로 연령과도 유의한 상관관계를 보인다. 따라서 본 연구는 언어장애 동반 여부와 언어 학적 증상에 따른 말소리장애 아동의 본질적인 기저 결함을 좀 더 타당하게 파악하기 위해서 연령과 자음정확도를 통제한 후에 무의 미 낱말 따라말하기의 수행력을 살펴보았다.

먼저 일반 아동과 언어장애를 동반하지 않은 순수말소리장애, 언어장애를 동반한 말소리장애, 언어장애만을 보이는 아동을 대상 으로 무의미 낱말 따라말하기 수행력을 문항, 음절, 음소 정확도를 이용하여 살펴보았다. 연령과 자음정확도를 통제한 후 살펴본 추 정 주변 평균은 네 집단 중 언어장애를 동반한 말소리장애 집단이 무의미 낱말 전체 문항 중 약 $59 \%$ 의 정확도를 보이면서 가장 낮은 수행력을 보였다. 반면에 순수말소리장애 집단은 약 $76 \%$ 의 문항 정 확도를 보이면서 일반 아동 집단보다도 높은 수행력을 보이는 것으 로 나타났다. 연령과 자음정확도를 공변량으로 한 공분산분석 결 과, 무의미 낱말 따라말하기의 문항 정확도에서 언어장애를 동반 한 말소리장애와 언어장애는 일반 아동과 순수말소리장애 보다 유 의하게 낮은 수행력을 보였다. 많은 선행연구에서 언어장애를 동반 한 말소리장애 아동은 말소리장애만을 가진 아동과 비교해 말 지 각, 음운인식, 음운기억, 낱말에 대한 기저 음운 표상과 관련된 과제 에서 더 큰 어려움을 보인다고 보고되고 있다(Lewis et al., 2011; Nathan, Stackhouse, Goulandris, \& Snowling, 2004; Sices, Taylor, Freebairn, Hansen, \& Lewis, 2007; Stoel-Gammon, 2011). 언어장 애를 동반한 말소리장애 아동에 대한 선행연구의 결과와 본 연구 결과는 일관성있게 언어장애를 동반한 말소리장애 아동이 말 처리 과정에서 광범위한 결함을 보임을 시사하고 있다. 언어장애를 동반 한 말소리장애는 순수말소리장애 아동과 비교해 말-언어처리 과정 
의 청지각적 처리능력, 음운기억, 음운표상, 음운 부호화, 말 운동 프로그램 전반에 걸쳐 제한을 보이고 그로 인해 무의미 낱말 따라 말하기 과제에 상대적으로 더 큰 어려움을 보인다고 할 수 있다. 주 목할만한 결과는 순수말소리장애 아동은 연령과 자음정확도를 통 제하고 무의미 낱말 따라말하기 수행력을 살펴보면 일반 아동보다 도 유의하게 높은 수행력을 보인다는 점이다. 이러한 결과는 순수 말소리장애 아동은 말-언어처리 과정상의 결함이 아닌 말 운동 실 행 또는 조음 자체의 어려움으로 인해 말 산출의 정확도가 떨어진 다고 할수 있다.

두번째로 본 연구에서는 말소리장애를 언어학적 증상에 따라 조 음장애, 음운지연, 일관적 음운장애, 비일관적 음운장애로 분류한 뒤에 무의미 낱말 따라말하기 수행력도 비교하였다. 연구결과, 비 일관적 음운장애 아동에게서 무의미 낱말 따라말하기 과제의 어 려움이 두드러지게 나타났다. 특히 연령과 자음정확도로 통제하기 전 문항 정확도 평균이 약 $37.6 \%$ 로 나타나 $78 \%$ 의 정확도를 보인 조 음장애 아동과 비교해 무의미 낱말 따라말하기 상의 큰 어려움을 보였다. 이러한 결과는 언어장애를 동반한 말소리장애 관련 선행연 구와 마찬가지로 비일관적 음운장애 아동이 다른 말소리장애 유형 과 상이한 기저 결함을 가지고 있음을 제안한다. 일반 아동이 보이 는 정상적인 조음변이성과 다르게 여러 오류형태를 포함하면서 비 일관된 산출을 빈번하게 보이는 비일관적 음운장애는 음운표상과 말 운동 프로그램을 포함하여 말 처리 과정상에서 광범위한 결함 을 보인다(Grunwell, 1981; Williams \& Stackhouse, 2000). 그로 인 해 비일관적 음운장애 아동은 병리적인 비일관성과 함께 무의미 낱말을 정확하게 따라말하는 과제에서도 어려움을 보인다. 반면에 조음장애는 다른 말소리장애 하위유형과 구별되게 무의미 낱말의 음소 수준에서의 실제 평균이 약 $95 \%$ 로 높은 정확도를 보이면서 무의미 낱말 따라말하기 과제 상에 어려움을 보이지 않았다. 본 연 구의 조음장애 아동과 관련된 결과는 학령기 말소리장애 아동을 대상으로 음운처리능력을 살펴본 $\mathrm{Pi}, \mathrm{So}$ 와 $\mathrm{Ha}$ (2020)의 연구결과 와 일관성이 있다. 선행연구에서는 말소리장애를 조음장애, 음운지 연, 음운장애로 분류한 뒤에 음운인식, 음운단기기억, 음운작업기 억, 빠른 자동 이름대기 능력을 살펴보았는데 음운단기기억 과제로 숫자 따라말하기와 더불어 본 연구에서 사용한 검사어 목록과 동 일한 무의미 낱말 따라말하기 과제를 사용하였다. 연구결과, 음운 처리능력을 살펴보는 여러 과제 중에서 무의미 낱말 따라말하기가 공통적으로 말소리장애 유무와 말소리장애 하위유형을 구별해주 는 과제로 나타났으며, 조음장애는 일반 아동과 동일한 수행력을 보이면서 다른 두 집단보다 유의하게 높았다. 이러한 결과는 본 연 구에서 사용한 무의미 낱말 따라말하기 과제가 말소리장애의 기저
결함을 확인하거나 특성에 따라 하위유형을 분류하는데 타당하게 사용될 수 있음을 제안하고 있다.

한편 무의미 낱말 따라말하기의 정확도는 분석 단위에 따라 말 소리장애 집단 비교 결과가 다소 다르게 나타났다. 언어학적 증상 에 따른 말소리장애 하위유형 별 비교에서 문항 정확도는 집단 간 유의한 차이가 나타나지 않은 반면에 음절과 음소 정확도에서는 집 단 간 차이가 유의하게 나타났다. 특히 사후검정 결과, 음절 정확도 면에서 비일관적 음운장애와 일관적 음운장애 간 유의한 차이가 없다가, 음소 정확도에서는 비일관적 음운장애가 일관적 음운장애 를 포함하여 다른 세 말소리장애 유형보다 유의하게 낮았다. 이러 한 결과는 문항 단위로 무의미 낱말 따라말하기 수행력을 평가하 는 방식은 편리하기는 하나, 말소리장애 유형 별 특성을 파악하기 에는 민감도가 떨어질 수 있음을 나타낸다. 따라서 말소리장애 유 형 별 특성을 파악하면서 감별진단하기 위해서는 문항보다는 음절 이나 음소 수준에서 무의미 낱말 따라말하기 수행력을 분석하는 것이 보다 더 민감하고 타당하다고 할 수 있다. 또한 본 연구에서는 무의미 낱말 따라말하기의 수행력을 양적인 면에서만 비교 분석하 였으나, 말소리장애 하위유형 별 특성을 보다 더 세밀하게 파악하 고 이를 감별진단의 근거자료로 사용하기 위해서는 무의미 낱말 따라말하기에서 나타난 오류에 대한 질적 분석이 추가로 이루어져 야한다.

본 연구결과를 종합해 보면 말소리장애 아동 가운데 언어장애 를 동반하거나 비일관적 음운장애를 보일 경우 무의미 낱말 따라 말하기 상의 어려움을 보일 가능성이 높다. 이러한 점은 두 말소리 장애 유형이 말-언어처리과정에서 청지각적 처리, 음운기억 및 부호 화, 음운표상, 말 운동 프로그램과 관련해서 결함이 있음을 시사한 다. 무의미 낱말을 듣고 정확하게 말하기 위해서는 말 처리 과정의 다양한 영역에 의존해야 하기 때문에 무의미 낱말 따라말하기 과 제만으로는 아동이 말 처리 과정 중 어느 영역에서 결함을 보이는 지 정확하게 확인하는 것이 쉽지 않다. 하지만 말소리장애 아동이 무의미 낱말 따라말하기 과제에서 어려움을 보일 경우 아동이 단 순히 조음이나 말 운동 실행 단계 상의 문제라기 보다는 좀 더 광범 위한 말-언어 체계와 처리 과정상의 어려움과 관계가 있으므로 차 별적인 중재 접근법이 필요하다. 또한 무의미 낱말을 따라말하기 위해서 필요한 말-언어 처리 과정과 요소는 읽기와 밀접한 관련이 있다(Catts, 1993; Stackhouse \& Wells, 1997). 따라서 본 연구에서 나타난 언어장애를 동반한 말소리장애와 비일관적 음운장애 아동 이 보이는 무의미 낱말 따라말하기 과제상의 어려움은 이 아동들 이 조음과 언어문제 외에도 학령기에 읽기 상에 문제를 복합적으 로 보일 수 있음을 제안한다(Bishop \& Adams, 1990; Catts, 1993; 
Sices et al., 2007; Skebo et al., 2013). 이러한 점은 궁극적으로 언어 장애를 동반한 말소리장애와 비일관적 음운장애 아동에게는 말소 리 산출의 정확도 향상만을 목표로 하기보다는 말지각, 음운기억, 음운표상, 말운동 프로그램 에서의 기저 결함을 확인하고 직접적 으로 중재해서 학령기에 두드러지게 나타날 수 있는 읽기 문제를 예방하는 것이 필요함을 시사한다.

\section{REFERENCES}

Bernthal, J., Bankson, N., \& Flipsen, P. (2017). Articulation and phonological disorders: speech sound disorders in children (8th ed.). Boston, MA: Pearson.

Bishop, D. V., \& Adams, C. (1990). A prospective study of the relationship between specific language impairment, phonological disorders and reading retardation. Journal of child psychology and psychiatry, 31(7), 1027-1050.

Catts, H. W. (1993). The relationship between speech-language impairments and reading disabilities. Journal of Speech, Language, and Hearing Research, 36(5), 948-958.

Conti-Ramsden, G., Botting, N., \& Faragher, B. (2001). Psycholinguistic markers for specific language impairment (SLI). Journal of Child Psychology and Psychiatry and Allied Disciplines, 42(6), 741-748.

Conti-Ramsden, G., \& Hesketh, A. (2003). Risk markers for SLI: a study of young language-learning children. International Journal of Language \& Communication Disorders, 38(3), 251-263.

Dodd, B. (1995). Differential diagnosis and treatment of children with speech disorder. London: Whurr.

Dodd, B. (2005). Differential diagnosis and treatment of children with of speech disorder (2nd ed.). London: Whurr.

Ellis Weismer, S., Tomblin, J. B., Zhang, X., Buckwalter, P., Chynoweth, J. G., \& Jones, M. (2000). Nonword repetition performance in school-age children with and without language impairment. Journal of Speech, Language, and Hearing Research, 43(4), 865-878.

Estes, K. G., Evans, J. L., \& Else-Quest, N. M. (2007). Differences in the nonword repetition performance of children with and without specific language impairment: a meta-analysis. Journal of Speech, Language, and Hearing Research, 50(1), 177-195.

Gathercole, S. E., \& Adams, A. M. (1993). Phonological working memory in very young children. Developmental Psychology, 29(4), 770-778.

Grunwell, P. (1981). The nature of phonological disability in children. London: Academic Press.

Ha, S., Kim, M., Seo, D., \& Pi (in press). Korean Articulation Phonology Pro- file (K-APP). Seoul: Human Brain Research and Consulting.

Holm, A., Crosbie, S., \& Dodd, B. (2007). Differentiating normal variability from inconsistency in children's speech: normative data. International Journal of Language \& Communication Disorders, 42(4), 467-486.

Jung, S. M., \& Ha, S. H. (2017). The relationship among nonword repetition, age, vocabulary and articulation ability. Communication Sciences \& Disorders, 22(1), 14-24.

Kim, M. J., Kim, S. J., Ha, J. W., \& Ha, S. (2015). A survey of co-morbidity and speech-language characteristics in speech sound disorders. Communication Sciences \& Disorders, 20(3), 446-455.

Kim, M., Pae, S., \& Park, C. (2007). Assessment of Phonology and Articulation for Children (APAC). Seoul: Human Brain Research \& Consulting Co.

Kim, Y. T., Hong, G. H., Kim, K. H., Chang, H. S., \& Lee, J. Y. (2009). Receptive and Expressive Vocabulary Test (REVT). Seoul: Seoul Community Rehabilitation Center.

Ko, Y., Seo, E., Oh, G., \& Kim, S. (2017). Comorbidity of language impairment according to gender, age, and severity in children with speech sound disorders. Journal of Speech-Language \& Hearing Disorders, 26(4), 99-109.

Lewis, B. A., Avrich, M. A. A., Freebairn, M. L. A., Taylor, H. G., Iyengar, S. K., \& Stein, C. M. (2011). Subtyping children with speech sound disorders by endophenotypes. Topics in Language Disorders, 31(2), 112-127.

Macrae, T., \& Tyler, AA. (2014). Speech abilities in preschool children with speech sound disorder with and without co-occurring language impairment. Language, Speech, and Hearing Services in Schools, 45(4), 302-313.

Nathan, L., Stackhouse, J., Goulandris, N., \& Snowling, M. J. (2004). The development of early literacy skills among children with speech difficulties. Journal of Speech, Language, and Hearing Research, 47(2), 377-391.

Pi, M., \& Ha, S. (2020). Classification of subgroups of children with speech sound disorders: a preliminary study. Communication Sciences \& Disorders, 25(1), 114-126.

Pi, M., So, K. B., Ha, S. H. (2020). Phonological processing ability of children with speech sound disorders in early elementary school years. Communication Sciences \& Disorders, 25(3): 1-14.

Shriberg, L. D., \& Austin, D. (1998). Comorbidity of speech-language disorder: implications for a phenotype marker for speech delay. In R. Paul (Ed.), The speech language connection (pp. 73-117). Baltimore, MD: Paul H. Brookes. Shriberg, L. D., Lewis, B. A., Tomblin, J. B., McSweeny, J. L., Karlsson, H. B., \& Scheer, A. R. (2005). Towards diagnostic and phenotype markers for genetically transmitted speech delay. Journal of Speech, Language, and Hearing Research, 48(4), 834-852. 
Shriberg, L. D., Lohmeier, H. L., Campbell, T. F., Dollaghan, C. A., Green, J. R., \& Moore, C. A. (2009). A nonword repetition task for speakers with misarticulations: the Syllable Repetition Task (SRT). Journal of Speech, Language, and Hearing Research, 52(5), 1189-1212.

Sices, L., Taylor, H. G., Freebairn, L., Hansen, A., \& Lewis, B. (2007). Relationship between speech-sound disorders and early literacy skills in preschoolage children: impact of comorbid language impairment. Journal of Developmental and Behavioral Pediatrics, 28(6), 438-447.

Skebo, C. M., Lewis, B. A., Freebairn, L. A., Tag, J., Ciesla, A. A., \& Stein, C. M. (2013). Reading skills of students with speech sound disorders at three stages of literacy development. Language, Speech, and Hearing Services in
Schools, 44(4), 360-373.

Snowling, M., \& Stackhouse, J. (1983). Spelling performance of children with developmental verbal dyspraxia. Developmental Medicine e Child Neurology, 25(4), 430-437.

Stackhouse, J., \& Wells, B. (1997). Children's speech and literacy difficulties. I: A psycholinguistic framework. London: Whurr Publishers.

Stoel-Gammon, C. (2011). Relationships between lexical and phonological development in young children. Journal of Child Language, 38(1), 1-34.

Williams, P., \& Stackhouse, J. (2000). Rate, accuracy and consistency: diadochokinetic performance of young, normally developing children. Clinical Linguistics \& Phonetics, 14(4), 267-293. 


\section{국문초록}

\section{말소리장애 유형별 무의미 낱말 따라말하기}

\section{하승희}

한림대학교 언어청각학부, 한림청각언어연구소

배경 및 목적: 본 연구는 말소리장애 평가를 위해 개발된 무의미 낱말 과제를 이용하여 말소리장애 동반문제와 하위유형에 따라 무의 미 낱말 따라말하기 수행력을 비교하면서 무의미 낱말 따라말하기 검사의 타당성과 유용성을 점검해보고자 하였다. 방법: 만 3-7세의 일반 아동 206 명과 말소리장애 아동 120 명, 언어장애 44 명을 대상으로 무의미 낱말 따라말하기 과제를 실시하고 문항, 음절, 음소별로 정확도를 측정하였다. 먼저 말소리장애 아동을 언어장애 동반여부에 따라 일반아동, 순수말소리장애, 언어장애를 동반한 말소리장애, 언어장애로 분류한 후 무의미 낱말 따라말하기 수행력을 연령과 자음정확도를 공변량으로 통제한 후 비교하였다. 또한 말소리장애 아 동을 언어학적 증상에 따라 조음장애, 음운지연, 일관적 음운장애, 비일관적 음운장애로 분류한 뒤에 동일한 방식으로 비교하였다. 결 과: 연령과 자음정확도를 통제한 후 언어장애 동반 여부에 따른 말소리장애 아동의 무의미 낱말 따라말하기 수행력을 비교한 결과, 순 수말소리장애 아동의 수행력이 일반 아동을 포함한 다른 집단보다 유의하게 높았으며 언어장애를 동반한 말소리장애 아동은 수행력 이 낮았다. 언어학적 증상에 따른 말소리장애 하위유형별 비교에서는 음절과 음소 수준에서만 집단간 차이가 유의하였으며, 비일관적 음운장애 아동이 유의하게 낮은 수행력을 보였다. 논의 및 결론: 본 연구의 무의미 낱말 따라말하기 과제를 통해 언어장애를 동반한 말 소리장애와 비일관적 음운장애 아동은 다른 말소리장애 유형과는 다른 말-언어 처리상의 결함을 가지고 있음을 확인 할 수 있다.

핵심어: 말소리장애, 언어장애 동반, 하위유형, 무의미 낱말 따라말하기

\section{참고문헌}

고유경, 서은영, 오경아, 김수진 (2017). 말소리장애아동의 성별, 연령별, 중증도에 따른 언어장애 동반비율. 언어치료연구, 26(4), 99-109.

김민정, 김수진, 하지완, 하승희 (2015). 말소리장애의 동반장애 유형 및 말-언어 특성에 관한 설문조사. Communication Sciences \& Disorders,

20(3), 446-455.

김민정, 배소영, 박창일 (2007). 아동용 발음평가. 서울: 휴브알앤씨.

김영태, 홍경훈, 김경희, 장혜성, 이주연 (2009). 수용·표현 어휘력 검사. 서울: 서울장애인종합복지관.

정소미, 하승희 (2017). 비단어 따라말하기와 연령, 어휘 및 조음능력과의 관계. Communication Sciences \& Disorders, 22(1), 14-24.

피민경, 소금빈, 하승희 (2020). 말소리장애 유무에 따른 초등학교 저학년 아동의 음운처리능력 비교 연구. Communication Sciences \& Disorders,

25(3), 696-709.

피민경, 하승희 (2020). 말소리장애 아동의 하위 유형 분류를 위한 예비 연구. Communication Sciences \& Disorders, 25(1), 114-126.

하승희, 김민정, 서동기, 피민경 (출판중). 한국 조음음운 프로파일. 서울: 휴브알앤씨.

\section{ORCID}

하승희(제1저자, 교신저자, 교수 https://orcid.org/0000-0003-2133-3720) 